\title{
A new method for 3D printing drugs: melting solidification printing process
}

\author{
Vivian N Coggiola1(iD), Juan Pablo Real ${ }^{1}$ (D) \& Santiago D Palma*,1 (iD \\ ${ }^{1}$ Unidad de Investigación y Desarrollo en Tecnología Farmacéutica (UNITEFA), CONICET \& Departamento de Cs \\ Farmacéuticas, Facultad de Ciencias Químicas, Universidad Nacional de Córdoba, Ciudad Universitaria, Córdoba 5000, Argentina \\ *Author for correspondence: Tel.: +54 351535 3865; sdpalma@unc.edu.ar

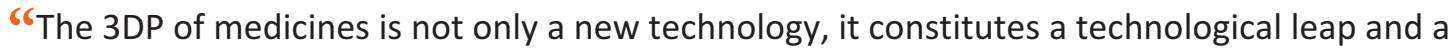 paradigm shift for pharmaceutical technology"

First draft submitted: 12 November 2020; Accepted for publication: 18 November 2020; Published online: 7 December 2020

Keywords: 3D printing • drug delivery $\bullet$ personalized medicine $\bullet$ pharmaceutical fabrication

Conventional manufacturing methods for oral administration forms are adapted to produce large batches of tablets of identical dosage form (same geometry, size and dosage). These methods are inflexible or not economically feasible to be adapted to the production of small, customized batches, either for special groups of patients or special geometries [1].

In recent decades, additive manufacturing, more commonly known as $3 \mathrm{D}$ printing (3DP), has become a promising tool in many production processes, including the medical and pharmaceutical industry. This technology enables on demand, layer-by-layer fabrication of 3D objects of almost any shape and size based on digital designs. In this way, it is easy to manufacture individualized objects, custom made [2]. This technology allows precise doses to be deposited, based on the initial 'ink' concentration and the physical dimensions of the formulation [3]. Pharmaceutical industry interest in 3DP has grown continuously since the US FDA approval of a 3D-printed drug in August 2015 [4].

The potential of 3DP in the pharmaceutical field is enormous. 3DP simplifies the traditional manufacturing process by reducing the usual steps (grinding, wet granulation, dry granulation, compression, coating, etc.) and allows for the variation of the sizes and geometry of the tablets; and it also allows the combination of materials of different nature [5]. Although this type of production cannot match the speed (it is 60-times slower) or the costs of large-scale production methods, the 3D printers' ability to produce different parts with enormous flexibility would allow the manufacture of pharmaceutical forms on demand, that is, to individualize drugs according to the needs of each patient, as well as it would allow combining different active ingredients (multidose tablets) [6].

\section{Technologies in 3DP of medicines}

It should be noted that various 3DP methods have been developed and patented for the production of medicines. The most used in obtaining medicines are classified into:

- Inkjet printing systems: powder bed printing;

- Extrusion printing systems: fused deposition model (FDM) and pressure-assisted microsyringe;

- Radiation printing systems: stereolithography and sintering selective laser.

The rationale behind 3DP is always the same: material is added layer by layer until the desired 3D shape is obtained. However, each of the different methods mentioned uses a completely different 3D printer and presents particular characteristics with advantages and disadvantages when used in in the production of pharmaceutical systems (Table 1).

Among the main disadvantages, it is possible to mention the use of materials that have not yet been approved for human use, the use of water or other solvents that must be removed later, the use of very high temperatures, the 


\begin{tabular}{|c|c|c|c|c|c|c|}
\hline Classification & Printing method & Process & Ink & Advantages & Disadvantages & Ref. \\
\hline Inkjet & PBP & $\begin{array}{l}\text { A binder solution or } \\
\text { suspension is deposited } \\
\text { on a bed of powders }\end{array}$ & $\begin{array}{l}\text { The binders are the same as } \\
\text { those used in wet granulation } \\
\text { (e.g., PVP) } \\
\text { Powder bed is composed of } \\
\text { polymeric excipients such as } \\
\text { different methacrylate entities, } \\
\text { derivatives of } \\
\text { polyvinylpyrrolidone or sugar } \\
\text { and polyol such as lactose or } \\
\text { mannitol } \\
\text { The API can be present in the } \\
\text { binder, in the powder bed or } \\
\text { both }\end{array}$ & $\begin{array}{l}\text { - High resolution } \\
\text { - High } \\
\text { drug-carrying } \\
\text { capacity }\end{array}$ & $\begin{array}{l}\text { - Possibility of cross } \\
\text { contamination from the use of } \\
\text { powders } \\
\text { - Requires prior preparation: } \\
\text { flow control, } \\
\text { selection/preparation of the } \\
\text { binder). High control of powder } \\
\text { flow level and moisture content } \\
\text { - Requires postprocessing: print } \\
\text { drying, slow solidification times } \\
\text { and shrinkage of bonded } \\
\text { material }\end{array}$ & {$[7,8]$} \\
\hline \multirow[t]{2}{*}{ Extrusion } & FDM & $\begin{array}{l}\text { A solid filament is } \\
\text { extruded through a } \\
\text { high-temperature } \\
\text { nozzle where it is } \\
\text { heated to a semi-liquid } \\
\text { state to be deposited }\end{array}$ & $\begin{array}{l}\text { Drug-loaded thermoplastic } \\
\text { polymer filaments. PVA is the } \\
\text { most widely used material. } \\
\text { Pharmaceutical HME technique is } \\
\text { usually used for drug loading }\end{array}$ & $\begin{array}{l}\text { - Inexpensive } \\
\text { method } \\
\text { - Great versatility } \\
\text { of filaments used } \\
\text { - Does not use } \\
\text { solvents (avoids } \\
\text { drying time) }\end{array}$ & $\begin{array}{l}\text { - Use of high temperatures } \\
\text { (around } 170^{\circ} \mathrm{C} \text { ) which is } \\
\text { inconvenient for heat sensitive } \\
\text { APIs } \\
\text { - Low drug carrying capacity } \\
\text { - Slow process }\end{array}$ & {$[9,10]$} \\
\hline & PAM & $\begin{array}{l}\text { A semisolid } \\
\text { formulation contained } \\
\text { in a syringe is extruded } \\
\text { through a needle to be } \\
\text { deposited }\end{array}$ & $\begin{array}{l}\text { Semi-solid formulation as } \\
\text { starting material (polymers, } \\
\text { suspensions, silicones, etc; } \\
\text { containing the API) }\end{array}$ & $\begin{array}{l}\text { - It can be done at } \\
\text { room temperature, } \\
\text { being a suitable } \\
\text { method for } \\
\text { thermolabile drugs }\end{array}$ & $\begin{array}{l}\text { - To achieve the proper viscosity, } \\
\text { solvents are used that require a } \\
\text { prolonged drying process } \\
\text { immediately after printing } \\
\text { (from } 24 \text { to } 48 \mathrm{~h} \text { ) } \\
\text { - Low drug carrying capacity } \\
\text { - Slow process }\end{array}$ & [8] \\
\hline \multirow[t]{2}{*}{ Radiation } & SLA & $\begin{array}{l}\text { A laser of radiation of } \\
\text { a certain wavelength } \\
\text { falls on a liquid resin }\end{array}$ & $\begin{array}{l}\text { Photoactive resins, which are } \\
\text { capable of polymerizing in } \\
\text { contact with UV or visible light } \\
\text { and which contain API }\end{array}$ & $\begin{array}{l}\text { - Produces high } \\
\text { resolution objects } \\
\text { at room } \\
\text { temperature. } \\
\text { - Quick process }\end{array}$ & $\begin{array}{l}\text { - Light-curing materials } \\
\text { - Carcinogenic risk of the } \\
\text { photopolymerization material } \\
\text { restricts its implementation and } \\
\text { requires washing processes that } \\
\text { ensure the complete removal of } \\
\text { the photocurable film }\end{array}$ & [11] \\
\hline & SLS & $\begin{array}{l}\text { A thermal laser draws } \\
\text { a specific pattern on a } \\
\text { bed of powder. The } \\
\text { molten and solidified } \\
\text { particles stick together } \\
\text { (sintered) }\end{array}$ & $\begin{array}{l}\text { Powder bed with photoactive } \\
\text { resins (polystyrene, ceramic } \\
\text { materials, glass, nylon and } \\
\text { metallic materials) and the API }\end{array}$ & $\begin{array}{l}\text { - Solvent-free } \\
\text { process } \\
\text { - Fast process }\end{array}$ & $\begin{array}{l}\text { - It uses powders that require } \\
\text { high temperatures and high } \\
\text { energy lasers to be sintered } \\
\text { - Requires postprocessing: dust } \\
\text { must be removed after printing }\end{array}$ & {$[12,13]$} \\
\hline
\end{tabular}

API: Active pharmaceutical ingredient; FDM: Fused deposition model; HME: Hot melt extrusion; PAM: Pressure-assisted microsyringe; PBP: Powder bed printing; PVA: Polyvinyl alcohol; SLA: Stereolithography; SLS: Sintering selective laser.

low drug loading capacity and the need for long operations before or after printing, such as loading thermoplastic filaments, formulating gels, controlling powder flow or drying forms.

Considering the different disadvantages of these methods, which thwart their use in pharmaceutical systems, especially if one thinks of elaboration in places such as pharmacies and hospitals, a new printing method was developed, which we have called melting solidification printing process (MESO-PP) [14].

\section{New proposed technology: MESO-PP}

The MESO-PP makes use of fusion/solidification techniques and adapts them to work along with 3D technology (Figure 1). This technique constitutes a simple, flexible and economical method. It is adaptable to small batches of drug manufacturing that allows it to be adapted to special groups of patients or special geometries.

The MESO-PP procedure uses materials that have a melting temperature in the range of 40 to $60^{\circ} \mathrm{C}$. Among these excipients, we can mention certain lipids such as gelucire or hydrophilic polymers such as polyethylene glycol, which mixed with other components or by themselves form what we call 'inks'. These inks are mixed in a solid state with one or more active ingredients (drugs) to make a premixed solid product (PSM), which can be used immediately or be stored in a stable form.

At the time of printing, the whole solid mixture is heated to a temperature above the melting point of the ink, with continuous agitation greater than 150 RPM. As a result of the heating, the ink melts and the active ingredient is incorporated in suspended or dissolved form. 
MESO-PP
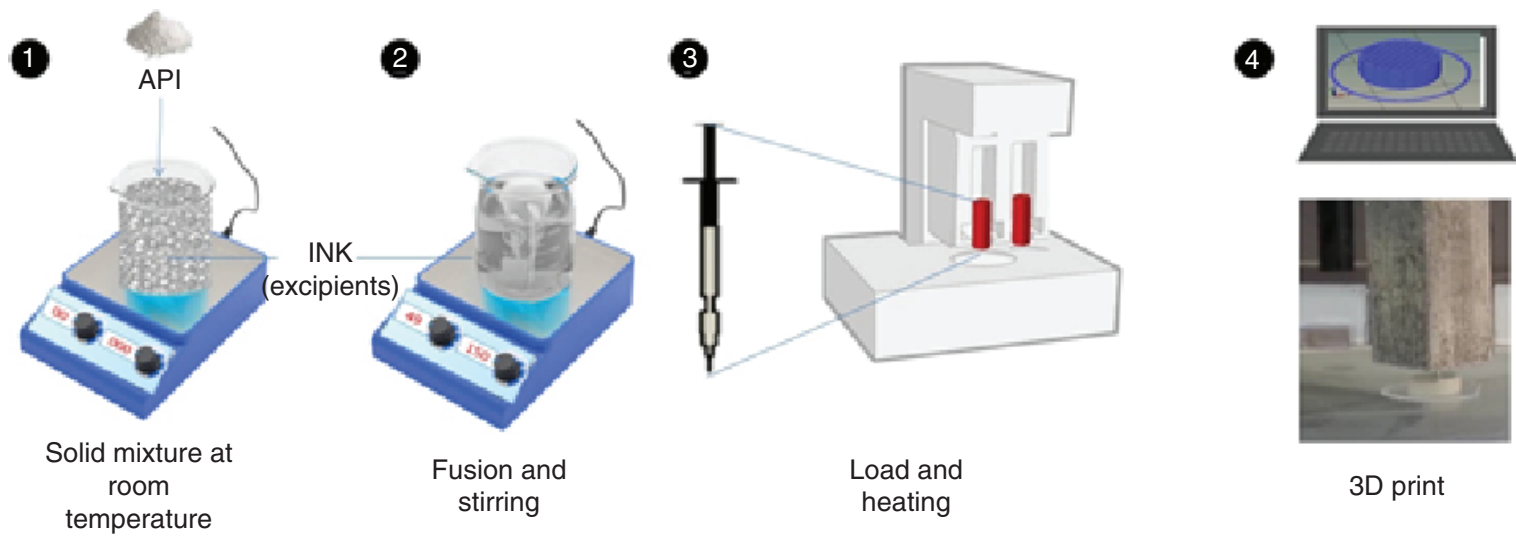

3D print

Figure 1. A graphical overview of the MESO-PP process. API: Active pharmaceutical ingredient.

Once the drug is incorporated, the mixture is ready to be heated (melted), extruded and deposited in a controlled manner on a printing surface (which can be cooled) following the pattern designed by computer to create a 3D image from the layer to layer material aggregate.

This process so far has several advantages over those previously mentioned [15]:

- It does not use water or any other solvent, which improves the stability of the drugs and reduces costs related to the removal of the solvent (drying process);

- It allows to obtain solid drugs without needing to use high temperatures with the consequent improvement in stability (it allows using the technique with thermosensitive drugs) and costs reduction due to the lower heat necessary;

- It uses safe materials, widely used in pharmaceutical technology (e.g., polymers and lipids) with the regulatory advantage that this brings;

- It does not require previous operations or processes (such as the manufacture of filaments or inks as is the case with FDM) with the consequent advantage of versatility and potential use in the manufacture of medicines on a reduced scale (pharmacies or hospitals);

- It is a versatile method that allows the incorporation of the asset(s) prior to printing and can be carried out in a single stage;

- The printers used for this method are portable, inexpensive and relatively simple to operate, making them eligible for deployment in pharmacies and points of patient care.

\section{A new trend?}

The 3DP of medicines is not only a new technology, it constitutes a technological leap and a paradigm shift for pharmaceutical technology. The medicinal specialties that we know today are prepared and packaged by the pharmaceutical industry for distribution and sale. 3DP could add to this concept a new type of custom medicinal specialty. These specialties would be configured in a digital design and they would be ready to be prepared at the points of patient care using previously validated processes and inks. For this to be possible, it would be necessary to have automatic, versatile and sufficiently robust methods and equipment so as not to require previous elaboration stages or postprocessing stages.

Until the appearance of MESO-PP, only the FDM technique fulfilled the requirements for decentralized and tailor-made production. This is probably one of the reasons why FDM leads the number of publications related to 3DP of medicines. The new technique patented by the National University of Cordoba (Argentina), complements FDM, providing even more and new advantages that could make it the method of choice for customizing medication. 
Financial \& competing interests disclosure

This work was supported by CONICET - ANPCyT. The authors have no other relevant affiliations or financial involvement with any organization or entity with a financial interest in or financial conflict with the subject matter or materials discussed in the manuscript apart from those disclosed.

No writing assistance was utilized in the production of this manuscript.

\section{Open access}

This work is licensed under the Attribution-NonCommercial-NoDerivatives 4.0 Unported License. To view a copy of this license, visit http://creativecommons.org/licenses/by-nc-nd/4.0

\section{References}

1. Real JP, Díaz Nocera A, Camacho N, Palma S. Manufacture of medicines through 3D printing: only for customized medicine or more? 3DMedNet (2018).

www.3dmednet.com/manufacture-of-medicines-through-3d-printing-only-for-customized-medicine-or-more/

2. Berman B. 3-D printing: the new industrial revolution. Business Horizons 55(2), 155-162 (2012).

3. Trenfield SJ, Goyanes A, Telford R et al. 3D printed drug products: nondestructive dose verification using a rapid point-and-shoot approach. Int. J. Pharm. 549(1-2), 283-292 (2018).

4. FDA (Food and Drug Administration-United States). Highlights of Prescribing Information - Spritam. (2015). www.accessdata.fda.gov/drugsatfda_docs/label/2016/207958s002lbl.pdf

5. Zhang J, Vo AQ, Feng X, Bandari S, Repka MA. Pharmaceutical additive manufacturing: a novel tool for complex and personalized drug delivery systems. AAPS PharmSciTech. 19(8), 3388-3402 (2018).

6. Norman J, Madurawe RD, Moore CMV, Khan MA, Khairuzzaman A. A new chapter in pharmaceutical manufacturing: 3D-printed drug products. Adv. Drug Deliv. Rev. 108, 39-50 (2017).

7. Daly R, Harrington TS, Martin GD, Hutchings IM. Inkjet printing for pharmaceutics - a review of research and manufacturing. Int. J. Pharm. 494(2), 554-567 (2015).

8. Goole J, Amighi K. 3D printing in pharmaceutics: a new tool for designing customized drug delivery systems. Int. J. Pharm. 499(1-2), 376-394 (2016).

9. Chia HN, Wu BM. Recent advances in 3D printing of biomaterials. J. Biol. Eng. 9, 4 (2015).

10. Goyanes A, Chang H, Sedough D et al. Fabrication of controlled-release budesonide tablets via desktop (FDM) 3D printing. Int. J. Pharm. 496(2), 414-420 (2015).

11. Wang J, Goyanes A, Gaisford S, Basit AW. Stereolithographic (SLA) 3D printing of oral modified-release dosage forms. Int. J. Pharm. 503(1-2), 207-12 (2016).

12. Fina F, Goyanes A, Gaisford S, Basit AW. Selective laser sintering (SLS) 3D printing of medicines. Int. J. Pharm. 529(1-2), 285-293 (2017).

13. Marro A, Bandukwala T, Mak W. Three-dimensional printing and medical imaging: a review of the methods and applications. Curr. Probl. Diagn. Radiol. 45(1), 2-9 (2016).

14. Real JP, Barberis ME, Camacho NM, Bruni S, Palma S. Design of novel oral ricobendazole formulation applying melting solidification printing process (MESO-PP): an innovative solvent-free alternative method for $3 \mathrm{~d}$ printing using a One-step concept and low temperature. Int. J. Pharm. 587, 119653 (2020).

15. Real JP, Barberis ME, Palma SD. Proceso de impresión 3D de medicamentos a baja temperatura, presión y sin uso de solventes-(MESO-PP). INPI - ACTA 20200101256, (2020). 